\title{
Effect of supplementing essential oils on the in vitro methane production and digestibility of wheat straw
}

\author{
Hundal JS, Wadhwa M and Bakshi MPS*
}

Department of Animal Nutrition, Guru Angad Dev Veterinary and Animal Science University, Ludhiana-141004, India

Corresponding author: Bakshi MPS, Department of Animal Nutrition, Guru Angad Dev Veterinary and Animal Science University, Ludhiana-141004, India, Tel: 09569105009; E-mail: bakshimps@yahoo.com

Rec date: March 12, 2016; Acc date: April 09, 2016; Pub date: April 15, 2016

Copyright: (c) 2016 Hundal JS, et al. This is an open-access article distributed under the terms of the Creative Commons Attribution License, which permits unrestricted use, distribution, and reproduction in any medium, provided the original author and source are credited.

\section{Abstract}

The study was taken up to assess the effect of the pure essential oils (EOs) viz. cinnamaldehyde, carvacrol, carvone and limonene supplemented individually at 1 to $5 \%$ levels of the substrate DM (wheat straw) on the in vitro methane production and fiber degradation in a $4 \times 7$ factorial design. Supplementation of cinnamaldehyde and carvon, irrespective of their level had significantly $(P<$ 0.01 ) higher net gas production (NGP), digestibility of neutral detergent fiber (NDFD) and true organic matter (TOMD), metabolizable energy (ME) availability and volatile fatty acids (VFAs) production from the substrate. The methane production was lowest $(P<0.01)$ in carvacrol followed by limonene and highest $(P<0.01)$ in carvone supplemented groups. Irrespective of the type of EO, the NGP and ME availability at $1 \%$ level of supplementation was comparable with control, while values of all other parameters were significantly $(P<0.01)$ lower than control and positive control. The NGP, NDFD and TOMD, ME availability, methane production and total and individual VFAs production was depressed significantly $(P<0.01)$ beyond $1 \%$ level of supplementation of EO. It was concluded that carvacrol or limonene supplementation beyond $1 \%$ level reduced the methane production but the digestibility of nutrients, volatile fatty acid production and ME availability from the substrate were also depressed significantly.

Keywords Essential oils; In vitro evaluation; Methane production; Nutrient digestibility

\section{Introduction}

Mitigation of enteric methane emission and decreasing the carbon footprints of ruminants is one of the pressing challenges faced in the ruminant production sector. Not withstanding, because of the intricate relationships existing between the efficiency of feed fermentation in the rumen and methanogenesis, mitigation options have to be evaluated not just in terms of their effect on methane or total green house gases emissions but also on other rumen functional parameters and on their final consequences on animal production.
The efficiency of energy and protein utilization in the rumen is relatively low and can be improved by the modulation of several metabolic pathways, including the inhibition of methane production and deamination in the rumen.

This low efficiency not only reduces production performance, but also contributes to the release of pollutants to the environment [1]. The efficiency can be improved by modulating the activity of specific rumen microbial populations involved in the metabolic pathways.

In recent years, the use of antibiotics as growth promoters in animal nutrition has been banned in the European Union because of its relation to the increase in the number of antibiotic-resistant bacteria to drugs which are used by humans. Consequently, new commercial additives are required that offer more safety, but can manipulate rumen fermentation.

Thus, additives of vegetative origin, considered to be natural products, have been proposed to livestock producers as possible replacers of growth promoting antibiotics. The enteric methane production depends on dietary factors like soluble sugars, dietary lipids, level of feeding, roughage to concentrate ratio, type of forage, stage of maturity of forage, rate of passage of digesta, efficiency of feed conversion, processing and supplementation [2-3].

Besides polluting the environment, it also represents $2-10 \%$ loss in gross energy intake of feed. Because of negative correlation of methane production with energy utilization in ruminants, many efforts have been made to inhibit its production and to re-channel hydrogen to produce more propionate and microbial mass. It can be mitigated by the antimicrobial activity of natural plant extracts [4,5], feed additives [6] and phytogenics [7].

Fruit and vegetable wastes are good sources of different plant secondary metabolites like tannins, saponins and essential oils [8,9]. Cinnamaldehyde - a phenylpropanoid [(2E)-3-phenylprop-2-enal] is present in the bark of cinnamon trees and other species of the genus Cinnamomum.

It is the main active component of cinnamon oil. Carvacrol is a monoterpenoid phenol [2-Methyl-5-(1-methylethyl)-phenol], with a characteristic pungent, warm odor and found in oregano (Origanum spp.). Limonene is a colorless liquid 
hydrocarbon classified as a cyclic terpene [1-Methyl-4-(1methylethenyl)-cyclohexene] and is found in the citrus fruits. Carvone belongs to the family terpenoids [2-Methyl-5-(1methylethenyl)-2-cyclohexenone] is most abundant in the oils from seeds of caraway (Carum carvi), spearmint (Mentha spicata), and dill.

All these EOs have wide spectrum of antimicrobial activity against gram-positive and/or negative bacteria. Essential oils develop their action against bacteria through the interaction with the cell membrane. This interaction causes conformational changes in the membrane and results in the leakage of ions across the cell membrane and the loss of the trans-membrane ionic gradient. In most cases, bacterial growth is reduced and, in some cases, microbial death occurs [10]. This mechanism of action makes these essential oils more effective against gram positive bacteria, where the cell membrane can interact directly with hydrophobic compounds of essential oils [11]. The present in vitro study was conducted to screen the best, amongst the 4 EOs used, and the level/dose at what these should be supplemented to get best response with respect to enteric methane mitigation; with least effect on digestibility of nutrients using wheat straw as a substrate.

\section{Material and Methods}

The EOs being aromatic in nature, are poorly soluble in water, and this causes many problems for studying their biological and pharmacological properties. Wadhwa et al. [12] revealed that amongst the different solvents like water, methanol, ethanol, petroleum ether and propylene glycol; EOs dissolved in methanol gave the best response with regards to in vitro NGP, digestibility of nutrients, methane and VFA production.

Therefore, pure EOs viz. cinnamaldehyde, carvacrol, limonene and carvone were procured from Sigma-Aldrich chemicals and their 1 to $5 \%$ solutions were made with pure methanol. The antimicrobial properties of 4 essential oils at $1-5 \%$ of substrate DM was assessed by using wheat straw (WS) as the substrate. The wheat straw sample was finely ground to pass through $1 \mathrm{~mm}$ screen of Willey mill. Since the essential oils were dissolved in pure methanol, therefore, besides using wheat straw as control; wheat straw plus methanol was used as positive control in this study.

\section{In vitro studies}

Three rumen fistulated rams were offered concentrate mixture (Maize 32 , barley 20 , soybean meal 15 , groundnut extraction 15, rice bran 15, mineral mixture 2 and common salt $1 \%$ each) and green fodder in 50:50 ratio on DM basis. The rumen contents were collected before feeding at 0900 in a thermos flask flushed with $\mathrm{CO}_{2}$ and maintained at $39^{\circ} \mathrm{C}$. The rumen contents were blended for 2-3 $\mathrm{min}$ in a blender and strained through four-layers of muslin cloth. The solution, containing $960 \mathrm{ml}$ distilled water, $0.16 \mathrm{ml}$ micro-mineral solution, $660 \mathrm{ml}$ bicarbonate buffer, $330 \mathrm{ml}$ macro-mineral solution and $1.6 \mathrm{ml}$ resazurine $(0.1 \%)$ were mixed in a Woulff flask (3 Litres capacity) with magnetic stirrer in a water bath at $39^{\circ} \mathrm{C}[13,14]$. The mixture was continuously flushed with $\mathrm{CO}_{2}$.

Then strained rumen liquor (SRL) was added to the buffer media in the ratio of 1:2. Essential oil dissolved in methanol; and methanol without essential oil were added to $100 \mathrm{ml}$ calibrated glass syringes (Haberle Labortechnik, Germany) containing $375 \pm 5 \mathrm{mg}$ wheat straw with buffered rumen fluid. Syringes were incubated in triplicate in a water bath at $39^{\circ} \mathrm{C}$ and swirled every 60 min over a $24 \mathrm{~h}$ incubation period. If the volume of gas in the syringe exceeded $70 \mathrm{ml}$ after $8 \mathrm{~h}$ the volume was recorded and the gas was expelled. After $24 \mathrm{~h}$, the volume of gas produced in each syringe was recorded and the contents of syringes were transferred to spout-less beaker, boiled with neutral detergent solution for assessing the true $\mathrm{OM}$ and NDF digestibility. Each in vitro gas production set was repeated thrice in order to check any variation in the net gas production and other parameters.

\section{Methane estimation}

For $\mathrm{CH}_{4}$ estimation, $200 \mathrm{mg}$ of substrate was incubated for $24 \mathrm{~h}$ with buffered rumen liquor and respective EO solution in triplicate. After the stipulated period, total gas production was measured. For $\mathrm{CH}_{4}$ estimation, representative gas was sampled from the headspace of syringe in an airtight syringe and injected into Netchrom 9100 gas chromatograph equipped with flame ionization detector (FID) and stainless steel column packed with Porapak-Q. The gas flow rates for $\mathrm{N}_{2}, \mathrm{H}_{2}$ and air were 15, 30 and $300 \mathrm{ml} \mathrm{min}^{-1}$, respectively. Temperature of injector oven, column oven and detector were 70, 50 and $100^{\circ} \mathrm{C}$, respectively. A 50/50 mixture of $\mathrm{CH}_{4}$ and $\mathrm{CO}_{2}$ (Spancan; Spantech Products Ltd., England) was used as a standard.

\section{Estimation of volatile fatty acid}

After $24 \mathrm{~h}$ of incubation, a $5 \mathrm{ml}$ aliquot of fluid from each syringe was mixed with $1 \mathrm{ml}$ of $25 \%$ meta-phosphoric and kept for $1 \mathrm{~h}$ at ambient temperature [15]. Thereafter, it was centrifuged at $5500 \mathrm{rpm}$ for $10 \mathrm{~min}$ and clear supernatant was collected and stored at $-20^{\circ} \mathrm{C}$ until analyzed.

The volatile fatty acids were estimated using Netchrom 9100 gas chromatograph equipped with glass column (packed with chromosorb 101) and flame ionization detector [16]. Temperature of injection port, column and detector was set at $250^{\circ} \mathrm{C}, 175^{\circ} \mathrm{C}$ and $270^{\circ} \mathrm{C}$, respectively. The flow rate of carrier gas $(\mathrm{N})$ through the column was $15 \mathrm{ml} \mathrm{min}^{-1}$; and the flow rate of $\mathrm{H}_{2}$ and air through FID was 30 and $300 \mathrm{ml} \mathrm{min}^{-1}$, respectively. Sample $(2 \mu \mathrm{l})$ was injected through the injection port using a Hamilton syringe $(10 \mu \mathrm{l})$.

Individual VFA's of the samples were identified on the basis of their retention time and their concentration (mmol) and calculated by comparing the retention time as well as the peak area of standards after deducting the corresponding blank values. 


\section{Analytical methods}

The finely ground samples of the substrate were analyzed for dry matter (DM), crude protein (CP), ether extract (EE) and total ash [17] and neutral detergent fiber (NDF) [18]. For ammonia estimation, $5 \mathrm{ml}$ of supernatant was mixed with $1 \mathrm{~N}$ $\mathrm{NaOH}$ and steam distillated and the $\mathrm{NH}_{3}$ evolved was collected in boric acid solution containing mixed indicator and titrated against $0.01 \mathrm{~N} \mathrm{H}_{2} \mathrm{SO}_{4}[17]$.

\section{Statistical analyses}

The data were analyzed by $4 \times 7$ factorial design [19], taking different EOs as one factor and levels of EOs as second factor. The data was analyzed by using SPSS [20] version 16.0 and the means were tested for the significant difference by using Tukey's b test.

\section{Results}

\section{Effect of type of essential oils irrespective of their level}

The results revealed that irrespective of the level of EO supplementation, NGP varied $(\mathrm{P}<0.01)$ from 54 (carvacrol) to $117 \mathrm{ml} / \mathrm{g} \mathrm{DM} / 24 \mathrm{~h}$ (carvone). The NGP, digestibility of NDF, true $\mathrm{OM}$ and $\mathrm{ME}$ availability from WS was similar in cinnamaldehyde and carvon supplemented groups, but significantly $(P<0.01)$ higher than that of carvacrol and limonene supplemented groups (Table 1).

Cinnamaldehyde had an edge over carvone as far as these parameters were concerned. Carvacrol had the lowest $(P<$ 0.01 ) digestibility of nutrients as compared to other supplemented groups.

Carvacrol had the lowest methane production followed by limonene supplemented groups, but significantly $(P<0.01)$ lower than that of cinnamaldehyde and carvone supplemented groups, at the cost of impaired digestibility of nutrients.

Supplementation of cinnamaldehyde and carvone resulted in lower $\mathrm{NH}_{3}-\mathrm{N}$ production as compared to carvacrol and limonene supplementation, but the differences were nonsignificant.

Supplementation of cinnamaldehyde resulted in significantly higher production of total $(P<0.05)$ and individual VFAs $(P<$ $0.01)$, carvone followed the trend (Table 2). This resulted in lower $(P<0.01) A$ : $P$ ratio.

The relative proportion of acetate decreased, while that of propionate increased $(P<0.01)$ when cinnamaldehyde or carvone was supplemented to the diet (Figure 1). The carvacrol and limonene supplementation to the substrate increased the relative proportion of butyrate significantly $(\mathrm{P}<$ 0.01).

Table 1: Effect of type of essential oil irrespective of its level on the in vitro net gas production, digestibility of nutrients and available ME using wheat straw as substrate.

\begin{tabular}{|c|c|c|c|c|c|}
\hline Parameters & Cinnamaldehyde & Carvacrol & Limonene & Carvone & PSE \\
\hline $\mathrm{NGP}, \mathrm{ml} / \mathrm{g} \mathrm{DM} / 24 \mathrm{~h}$ & $115.19^{c}$ & $54.02^{\mathrm{a}}$ & $91.32^{\mathrm{b}}$ & $117.42^{\mathrm{c}}$ & 1.65 \\
\hline NDFD, $\%$ & $22.29^{c}$ & $4.07^{a}$ & $10.15^{b}$ & $20.85^{c}$ & 0.84 \\
\hline TOMD, \% & $32.75^{\mathrm{c}}$ & $18.54^{a}$ & $23.15^{b}$ & $31.59^{c}$ & 0.70 \\
\hline $\mathrm{ME}, \mathrm{MJ} / \mathrm{kg} \mathrm{DM}$ & $5.54^{\mathrm{C}}$ & $4.06^{a}$ & $4.90^{\mathrm{b}}$ & $5.51^{\mathrm{C}}$ & 0.19 \\
\hline $\mathrm{CH}_{4}, \mathrm{ml} / 100 \mathrm{mg} / 24 \mathrm{~h}$ & $2.16^{c}$ & $0.82^{a}$ & $1.65^{\mathrm{b}}$ & $2.35^{\mathrm{c}}$ & 0.09 \\
\hline $\mathrm{NH}_{3}, \mathrm{mg} / \mathrm{dl}$ & 0.063 & 0.068 & 0.066 & 0.063 & 0.001 \\
\hline
\end{tabular}

Table 2: Effect of type of essential oil irrespective of its level on the in vitro volatile fatty acid production (mM/dl).

\begin{tabular}{|c|c|c|c|c|c|}
\hline Parameters & Cinnamaldehyde & Carvacrol & Limonene & Carvone & PSE \\
\hline TVFA $^{*}$ & $4.05^{d}$ & $2.89^{a}$ & $3.34^{b}$ & $3.78^{c}$ & 0.01 \\
\hline Acetate $^{* *}$ & $2.98^{d}$ & $2.15^{a}$ & $2.49^{b}$ & $2.80^{c}$ & 0.02 \\
\hline Propionate $^{* *}$ & $0.84^{d}$ & $0.56^{a}$ & $0.65^{b}$ & $0.76^{c}$ & 0.01 \\
\hline Butyrete $^{* *}$ & $0.23^{d}$ & $0.18^{a}$ & $0.20^{\mathrm{b}}$ & $0.21^{c}$ & 0.003 \\
\hline$A: P$ & $3.65^{a}$ & $4.20^{c}$ & $4.14^{c}$ & $3.87^{b}$ & 0.03 \\
\hline
\end{tabular}




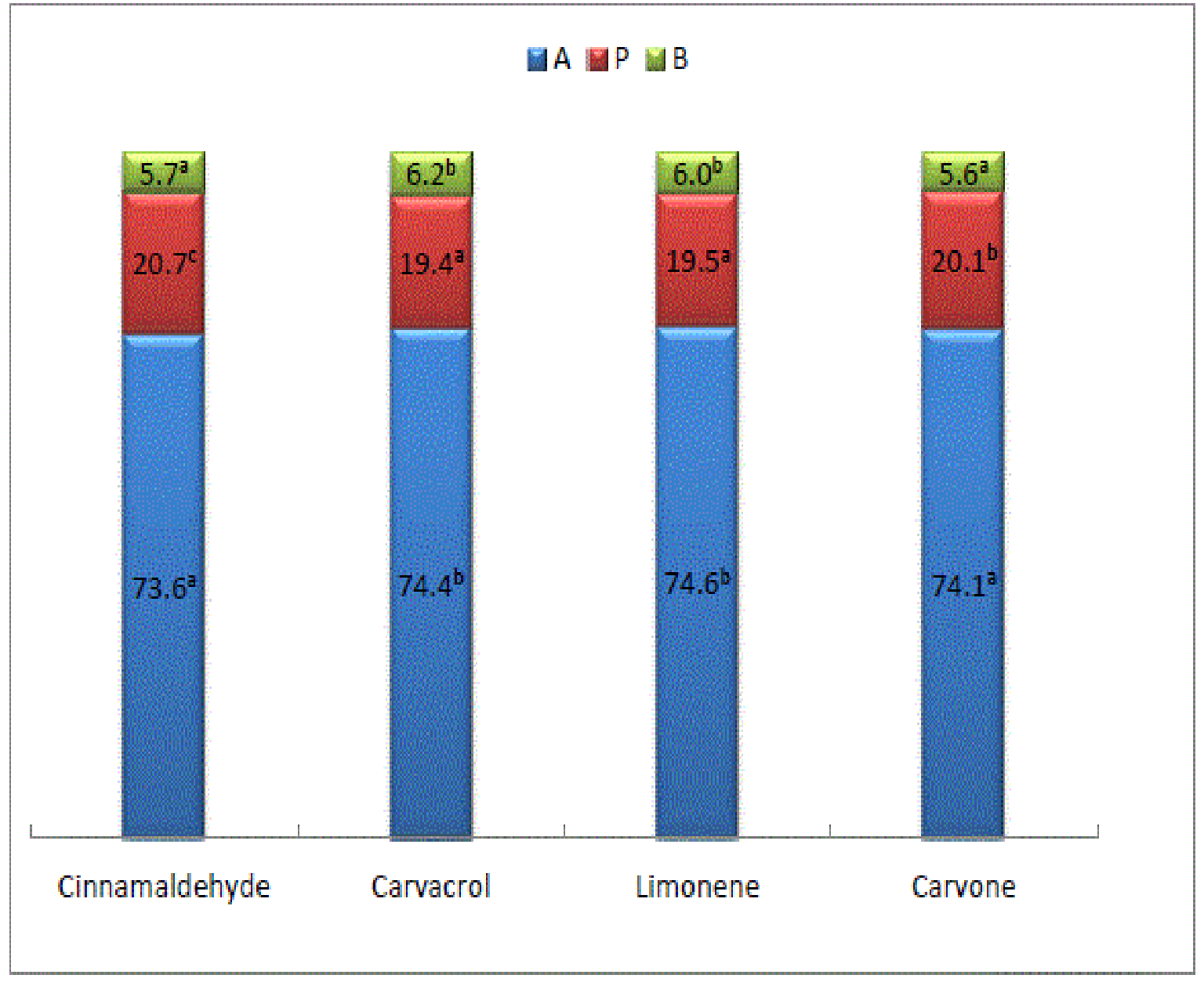

Figure 1: Effect of type of essential oils on relative proportion of volatile fatty acids, irrespective of level. Figures with different superscripts ${ }^{a, b, c}$ in a particular parameter differ significantly, $\mathrm{P}<0.01$.

\section{Effect of level of essential oils, irrespective of} their type

The NGP at $1 \%$ level of EOs supplementation was comparable to control (WS), but significantly higher $(P<0.01)$ than the positive control (WS+ methanol). Beyond $1 \%$ the NGP from substrate (wheat straw) decreased $(P<0.01)$ linearly with increase in level of EO supplementation, mainly due to linear decrease $(P<0.01)$ in the digestibility of NDF and that of true organic matter (TOM) as compared to both control as well as positive control (Table 3).
The ME availability from the substrate followed the similar trend, except that beyond $2 \%$ there was no significant depression in ME availability. The methane production was comparable in control, positive control and upto $1 \%$ level of EO supplementation. As compared to control there was a significant $(P<0.01)$ depression in methane production, beyond $1 \%$ level of essential oil supplementation. The $\mathrm{NH}_{3}-\mathrm{N}$ was comparable in positive control and at all the levels of EO supplementation, but was depressed significantly in all the groups as compared to control group.

Table 3: Effect of level of essential oil (\%) irrespective of its type on in vitro net gas production, digestibility of nutrients using wheat straw as substrate.

\begin{tabular}{|c|c|c|c|c|c|c|c|c|}
\hline \multirow[t]{2}{*}{ Parameters } & \multirow[t]{2}{*}{ ws } & \multirow[t]{2}{*}{ WS + Methanol } & \multicolumn{5}{|c|}{ WS + Methanol + Essential oil } & \multirow[t]{2}{*}{ PSE } \\
\hline & & & 1 & 2 & 3 & 4 & 5 & \\
\hline NGP, ml/g DM/24h & $139.71^{\mathrm{e}}$ & $121.68^{d}$ & $140.35^{e}$ & $94.26^{c}$ & $79.96^{c}$ & $48.64^{b}$ & $36.82^{a}$ & 2.24 \\
\hline NDFD, $\%$ & $32.03^{e}$ & $29.60^{e}$ & $22.60^{d}$ & $11.23^{c}$ & $4.96^{\mathrm{b}}$ & $1.68^{\mathrm{ab}}$ & $1.09^{a}$ & 1.04 \\
\hline TOMD, \% & $41.54^{\mathrm{e}}$ & $38.60^{e}$ & $33.89^{d}$ & $24.01^{\mathrm{c}}$ & $18.78^{b}$ & $16.08^{a b}$ & $12.64^{a}$ & 0.88 \\
\hline $\mathrm{ME}, \mathrm{MJ} / \mathrm{kg} \mathrm{DM}$ & $6.13^{\mathrm{c}}$ & $5.70 b^{c}$ & $5.83^{c}$ & $4.80^{\mathrm{ab}}$ & $4.44^{\mathrm{a}}$ & $3.89^{a}$ & $4.24^{\mathrm{a}}$ & 0.25 \\
\hline
\end{tabular}




\begin{tabular}{|c|c|c|c|c|c|c|c|c|}
\hline $\mathrm{CH}_{4}, \mathrm{ml} / 100 \mathrm{mg} \mathrm{DM} / 24 \mathrm{~h}$ & $2.11^{\mathrm{C}}$ & $1.95^{c}$ & $2.02^{\mathrm{c}}$ & $1.89^{b}$ & $1.56^{\mathrm{b}}$ & $0.87^{a}$ & $0.91^{\mathrm{a}}$ & 0.12 \\
\hline $\mathrm{NH}_{3}, \mathrm{mg} / \mathrm{dl}$ & $0.320^{\mathrm{b}}$ & $0.020^{a}$ & $0.019^{a}$ & $0.022^{\mathrm{a}}$ & $0.023^{a}$ & $0.025^{a}$ & $0.024^{a}$ & 0.002 \\
\hline
\end{tabular}

WS: Wheat straw; PSE: Pooled standard error; Figures with different superscripts ${ }^{a, b, c, d, e}$ in a row differ significantly, $\mathrm{P}<0.01$

The TVFAs and acetate production in positive control (WS + Methanol) was depressed significantly $(\mathrm{P}<0.01)$ as compared to the control group, but propionate and butyrate production was similar in both the groups (Table 4). Amongst the EO supplemented groups, the TVFAs and individual VFAs production were highest at $1 \%$ level of supplementation, but significantly $(P<0.01)$ lower than control and positive control groups.

Beyond $1 \%$ level of supplementation, these parameters decreased $(P<0.01)$ linearly, with increase in level of supplementation of essential oils. Reverse but significant $(\mathrm{P}<$ 0.01 ) trend was observed in case of acetate to propionate ratio, which increased $(P<0.01)$ with increase in level of supplementation of essential oils.

The significant depression in the production of TVFAs and individual VFAs could be due to significantly $(P<0.01)$ reduced digestibility of substrate. Amongst the EO supplemented groups, the relative proportion of acetate increased $(P<0.01)$ linearly, while that of propionate decreased linearly, with the increase in level of EO supplementation.

Table 4: Effect of level of essential oil (\%) irrespective of its type on the in vitro volatile fatty acid production (mM/dl).

\begin{tabular}{|c|c|c|c|c|c|c|c|c|}
\hline \multirow[t]{2}{*}{ Parameters } & \multirow[t]{2}{*}{ ws } & \multirow[t]{2}{*}{ WS + Methanol } & \multicolumn{5}{|c|}{ WS + Methanol + Essential oil } & \multirow[t]{2}{*}{ PSE } \\
\hline & & & 1 & 2 & 3 & 4 & 5 & \\
\hline TVFA & 5.219 & $4.74^{f}$ & $3.92^{\mathrm{e}}$ & $3.28^{\mathrm{d}}$ & $2.78^{\mathrm{C}}$ & $2.37^{\mathrm{b}}$ & $2.28^{a}$ & 0.02 \\
\hline Acetate $(\mathrm{A})$ & $3.82^{f}$ & $3.37^{e}$ & $2.86^{d}$ & $2.42^{\mathrm{c}}$ & $2.12^{\mathrm{b}}$ & $1.83^{a}$ & $1.78^{a}$ & 0.02 \\
\hline Propionate $(\mathrm{P})$ & $1.07^{e}$ & $1.07^{\mathrm{e}}$ & $0.84^{d}$ & $0.67^{c}$ & $0.51^{\mathrm{b}}$ & $0.40^{a}$ & $0.38^{a}$ & 0.01 \\
\hline Butyrate & $0.32^{\mathrm{e}}$ & $0.31^{\mathrm{e}}$ & $0.21^{d}$ & $0.18^{c}$ & $0.15^{\mathrm{b}}$ & $0.14^{b}$ & $0.11^{\mathrm{a}}$ & 0.004 \\
\hline$A: P$ & $3.58^{\mathrm{b}}$ & $3.15^{\mathrm{a}}$ & $3.45^{\mathrm{b}}$ & $3.80^{\mathrm{c}}$ & $4.40^{\mathrm{d}}$ & $4.62^{\mathrm{e}}$ & $4.74^{\mathrm{e}}$ & 0.04 \\
\hline \multicolumn{9}{|l|}{ Relative proportion, $\%$} \\
\hline Acetate & $73.38^{b}$ & $71.01^{\mathrm{a}}$ & $73.22^{b}$ & $74.46^{\mathrm{c}}$ & $76.58^{d}$ & $76.94^{d}$ & $78.15^{\mathrm{e}}$ & 0.26 \\
\hline Propionate & $20.54^{c}$ & $22.56^{\mathrm{e}}$ & $21.36^{d}$ & $19.95^{c}$ & $17.86^{b}$ & $16.70^{\mathrm{a}}$ & $16.56^{a}$ & 0.18 \\
\hline Butyrate & $6.08^{\mathrm{bc}}$ & $6.43^{c}$ & $5.42^{\mathrm{a}}$ & $5.59^{a b}$ & $5.56^{\mathrm{ab}}$ & $6.31^{c}$ & $5.09^{a}$ & 0.15 \\
\hline
\end{tabular}

PSE: Pooled standard error; TVFA: Total volatile fatty acids; Figures with different superscripts a,b,c,d,e,f,g in a row differ significantly, $\mathrm{P}<0.01$.

\section{Discussion}

Irrespective of the dose of EOs, supplementation of cinnamaldehyde had edge over other EOs as far as NGP, in vitro digestibilities, volatile fatty acid production and $A$ : $P$ ratio was concerned, but methane production was depressed significantly in carvacrol and limonene as compared to cinnamaldehyde and carvone. Earlier studies also revealed that peppermint [21,22], eucalyptus [23], thyme [24] cinnamon [25] and lemon [26] oils modified rumen microbial fermentation by decreasing ammonia $\mathrm{N}$ concentration through their impact on hyper-ammonia producing bacteria resulting in reduced deamination of amino acids, reduce methane emission, protozoa count and alter molar ratios of short chain fatty acids [27-30]. The anti-methanogenic effect of EOs in the rumen could be attributed to the presence of terpeniods and phenylpropanoids in oils. The EOs differ in chemical composition and have different effect on the same microbes. Different groups of rumen microbes also differ in sensitivity to the same EO. The EO containing a phenolic (e.g. carvacrol) or a carbonyl (e.g. cinnamaldehyde) compound demonstrated a stronger antimicrobial activity than EO that contains monoterpenes. Interactions among different EO and different EO components may affect their antimicrobial activity [31]. Arfa et al. [32] also reported that antimicrobial activity of carvacrol was related to its chemical structure and can be accumulated in the cell membrane. Its hydrogen-bonding ability and its proton-release ability may induce conformational modification of the membrane resulting in the cell death.

Irrespective of the EO supplemented, the NGP, digestibility of NDF and TOM, total and individual VFA and methane production were depressed linearly with the increase in dose of EOs. Similar trend in reduction in methane production with depression in the digestibility of nutrients was observed, when peppermint or clove oil extract were added to the substrate $[21,33,34]$. It is likely that the use of high doses of plant extracts and/or their secondary metabolites with antimicrobial activity decreased total microbial activity and diet fermentability [35]. Similar to ionophores like monensin (banned in EU since 2006), polyunsaturated fatty acids and 
essential oils act against gram positive bacteria, favouring propionate producing bacteria in the rumen, thereby encouraging alternative hydrogen sink to methane propionate [36]. Linolenic acid, linoleic acid and Allium arenarium oil (garlic oil) reduced methane by $71 \%, 51 \%$ and $36 \%$ respectively, in vitro [37]. Patra \& Yu [38] reported that clove oil, eucalyptus oil, garlic oil, origanum oil, and peppermint oil significantly reduced methane production with increasing doses as compared with the control. However, apparent degradability of DM and NDF decreased linearly with increasing doses by all EOs except garlic oil. All the EOs decreased the abundance of archaea, protozoa, and major cellulolytic bacteria (Fibrobacter succinogenes, Ruminococcus flavefaciens, and $R$. albus) linearly with increasing EO doses.

As compared to control, the addition of EOs depressed ( $\mathrm{P}<$ 0.01 ) the ammonia- $N$ concentration in the present study, confirming the earlier report [39]. Moreover, individual VFA proportions were affected by the dose of additives. The acetate to propionate ratio increased $(P<0.01)$ with increase in level of supplementation of essential oils. Improved A:P ratio was also observed on thymol supplementation [40]. Higher doses of cinnamon oil and cinnamaldehyde decreased total VFA and ammonia- $N$ concentrations, although cinnamaldehyde had stronger effects compared with cinnamon oil $[38,41]$.

\section{Conclusion}

It was concluded that carvacrol or limonene supplementation beyond $1 \%$ level reduced the methane production but the digestibility of nutrients, volatile fatty acid production and ME availability from the substrate were also depressed significantly.

\section{Acknowledgement}

It is to acknowledge that the work was conducted under National Agriculture Innovative Project of ICAR entitled "Rumen microbial diversity in domesticated and wild ruminants and impact of additives on methanogenesis and utilization of poor quality fibrous feeds"

\section{References}

1. Tamminga S (1993) Influence of feeding management on ruminant fiber digestibility. In: Jung HG, Buxton DR, Hatfield RD, Ralph J. (Eds.), Forage Cell Wall Structure and Digestibility. Madison, WI: American Society for Agronomy-Crop Science Society of America-Soil Science Society of America: 571-602.

2. Bakshi MPS, Wadhwa M (2009) Dietary manipulation for mitigation of enteric methane emission. Lead paper 5th Asian Buffalo Conference, Lahore. Proc. published in Pakistan Journal of Zoology 9: 887-893.

3. Bakshi MPS, Wadhwa M, Lamba JS, Hundal JS (2014) Methane production potential of feedstuffs and its implications. In: Baksh MPS \& wadhwa M (Eds.), Recent Advances in Animal Nutrition Pp: 79-98.
4. Bakshi MPS, Wadhwa M (2010) Significance of plant secondary metabolites in relation to methane production by ruminants. In: Pattanaik AK, Verma AK and Dutta N (Eds.) Animal nutrition: strategies for environment protection and poverty alleviation. Volume I. Proceedings of VII Biennial Animal Nutrition Association Conference pp: 25-28.

5. Bakshi MPS, Wadhwa M (2012) Herbal feed additives- Role in Animal Nutrition. In: Mehra UR, Singh P, Verma AK (Eds.), Animal Nutrition-Advances and Development Pp: 707-733.

6. Wadhwa M, Bakshi MPS (2009) Animal agriculture and greenhouse gas emission: mitigation strategies. In: Pattanaik AK, Verma AK, Kamra DN, Sharma K (Eds.), Animal nutritionpreparedness to combat challenges pp: 119-122.

7. Bakshi MPS, Wadhwa M (2011) Phytogenics: Role in enteric methane mitigation and performance of animals. In: Chaturvedi VB, Dutta N, Verma AK, Singh P \& Kamra DN (Eds.), Nutritional interventions for clean and green livestock production $\mathrm{Pp}$ : 180-184.

8. Wadhwa M, Bakshi MPS (2013) Utilization of fruit and vegetable wastes as livestock feed and as a substrate for generation of other value added products. Harinder PS Makkar (Ed). Food and Agriculture Organization of United Nations Pp: 56.

9. Wadhwa M, Bakshi MPS, Makkar HPS (2015) Wastes to worth: value added products from fruit and vegetable wastes. Commonwealth Agricultural Bureau Reviews 10: 043.

10. Cox SD, Mann CM, Markam JL (2001) Interaction between components of the essential oil of Melaleuca alternifolia. Journal of Applied Microbiology 91: 492-497.

11. Cimanga K, Kambu K, Tona L, Apers S, Bruyne T, et al. (2002) Correlation between chemical composition and antibacterial activity of essential oils of some aromatic medicinal plants growing in the Democratic Republic of Congo. Journal of Ethnopharmacology 79: 213-220.

12. Wadhwa M, Hundal JS, Kaur K, Bakshi MPS (2014) Effect of essential oils dissolved in different solvents on the in-vitro methane production. Animal Nutrition and Feed Technology 14: 59-67.

13. Menke KH, Rabb L, Salewski A, Steingass H, Fritz D, et al. (1979) The estimation of the digestibility and ME content of ruminant feedstuffs from the gas production when they are incubated with rumen liquor in vitro. Journal of Agricultural Science, Cambridge 93: 217-222.

14. Menke KH, Steingass H (1988) Estimation the energetic feed value obtained by chemical analysis and in vitro gas production using rumen fluid. Animal Research and Development 28: 7-55.

15. Erwin ES, Macro GA, Emery EM (1961) Volatile fatty acid analysis of blood and rumen fluid by gas chromatograph. Journal of Dairy Science 44: 1768-1771.

16. Cottyn BG, Boucque CV (1968) Rapid method for the gaschromatographic determination of volatile fatty acids in rumen fluid. Journal of Agriculture and Food Chemistry 16: 105-107.

17. AOAC (2000) Official Methods of Analysis. (7thedn) Association of Analytical Chemists, Gaithersburg, Maryland, USA.

18. Robertson JB, Van Soest PJ (1991) The detergent system of analysis and its application to human foods. In: James W.P.T, \& Theander O (Eds.), The Analysis of Dietary Fibre in Food. Marcel Dekker, Inc. New York Pp: 123-158.

19. Snedecor GW, Cochran WG (1994) Statistical Methods. (7thedn) Oxford and IBH Publications, New Delhi. 
20. SPSS (2007) Statistical packages for social sciences: Version 16, SPSS Inc., Ilinois, USA.

21. Agarwal N, Shekhar C, Kumar R, Chaudhary LC, Kamra DN, et al. (2009) Effect of peppermint oil on in vitro methanogensis and fermentation of feed with buffalo rumen liquor. Animal Feed Science and Technology 148: 321-327.

22. Ozkan CO, Kamalak A, Atalay Al, Tatliyer A, Kaya E, et al. (2015) Effect of peppermint (Mentha piperita) essential oil on rumen microbial fermentation of barley grain. Journal of Applied Animal Research 43: 287-290.

23. Sallam SMA, Bueno ICS, Nasser ME, Abdalla AL (2010) Effect of eucalyptus (Eucalyptus citriodora) fresh or residue leaves on methane emission in vitro. Italian Journal of Animal Science 9: 299-303.

24. Castillejos L, Calsamiglia S, Martín-Tereso J, Wijlen TH (2008) In vitro evaluation of effects of ten essential oils at three doses on ruminal fermentation of high concentrate feedlot-type diets. Animal feed science and technology 145: 259-270.

25. Fraser GR, Chaves AV, Wang Y, McAllister TA, Beauchemin KA, et al. (2007) Assessment of the effects of cinnamon leaf oil on rumen microbial fermentation using two continuous culture systems. Journal of Dairy Science 90: 2315-2328.

26. Castillejos L, Calsamiglia S, Ferret A (2006) Effect of essential oils active compounds on rumen microbial fermentation and nutrient flow in in vitro systems. Journal of Dairy Science 89: 2649-2658.

27. Sallam SMA, Abdelgaleil SAM, Bueno ICS, Nasser MEA, Araujo RC, et al. (2011) Effect of some essential oils on in vitro methane emission. Archies Animal Nutrition 3: 203-214.

28. Sallam SMA, Morsy AS, Soltan YA, Alencar SM, Abdalla AL, et al. (2012) Antimethanogenic activity of commercial essential oils products. Proc. 14th Int. Seminar of FAO-CIHEAM Sub-Network on sheep \& Goat Nutrition and 2 nd Symp. Low input Breeds. Feeding and management strategies to improve livestock productivity, welfare and product quality under climate changes.

29. Sallam SMA, Abdalla AL (2011) Antimethanogenic and antiprotozoal effect of some essential oils in vitro. Egyptian Journal of Animal Production 48: 203-215.

30. Soltan YA, Morsy AS, Araujo RC, Elziat HM, Sallam SMA, et al. (2011) Carvacrol and eugenol as modifiers of rumen microbial fermentation and methane production in vitro. Proc. Of 4th Animal Wealth Research Conference in the middle East and North Africa pp: 354-364.
31. Cobellis G, Trabalza-Marinucci M, Marcotullio MC, Yu Z (2016) Evaluation of different essential oils in modulating methane and ammonia production, rumen fermentation, and rumen bacteria in vitro. Animal Feed Science and Technology 215: 25-36.

32. Arfa AB, Combes S, Preziosi-Belloy L, Gontard N, Chalier P, et al. (2006) Antimicrobial activity of carvacrol related to its chemical structure. Letters in Applied Microbiology 43: 149-154.

33. Patra AK, Kamra DN, Agarwal N (2006) Effect of spices on rumen fermentation, methanogenesis and protozoa counts in in vitro gas production test. International Congress Series 1293: 176-179.

34. Rira M, Chentli A, Boufenera S, Bousseboua H (2015) Effects of plants containing secondary metabolites on ruminal methanogenesis of sheep in vitro. International Conference on Technologies and Materials for Renewable Energy, Environment and Sustainability, TMREES15. Energy Procedia 74: 15-24.

35. Cardozo PW, Calsamiglia S, Ferret A, Kamel C (2004) Effects of natural plant extracts on ruminal protein degradation and fermentation profiles in continuous culture. Journal of Animal Science 82: 3230-3236.

36. Frater $P$ (2014) Feed additives in ruminant nutrition. Can feed additives reduce methane and improve performance in ruminants? EBLEX, Agriculture and Horticulture Development Board. UK.

37. Lewis KA, Tzilivakis J, Green A, Warner DJ, Stedman A, et al. (2013) Review of substances/agents that have direct beneficial effect on the environment: mode of action and assessment of efficacy. European Food Safety Authority (EFSA) pp: 182

38. Patra AK, Yu Z (2012) Effects of essential oils on methane production and fermentation by and abundance and diversity of rumen microbial populations. Applied and Environmental Microbiology 78: 427-4280.

39. Busquet M, Calsamiglia S, Ferret A, Kamel C (2006) Plant extracts affect in vitro rumen microbial fermentation. Journal of Dairy Science 89: 761-771.

40. Evans JD, Martin SA (2000) Effects of thymol on ruminal microorganisms. Current Microbiology 41: 336-340.

41. Busquet M, Calsamiglia S, Ferret A, Cordozo PW, Kamel C, et al. (2005) Effect of garlic oil and four of its compounds on rumen microbial fermentation. Journal of Dairy Science 88: 4393-4404. 